\title{
EFFECTS OF FOLIAR UREA, POTASSIUM AND ZINC SULPHATE TREATMENTS BEFORE AND AFTER FLOWERING ON GRAIN YIELD, TECHNOLOGICAL QUALITY AND NUTRIENT CONCENTRATIONS OF WHEAT
}

\author{
BARUT, $\mathrm{H}$. \\ East Mediterranean Agricultural Research Institute, 01321 Adana, Turkey \\ (e-mail: barut.hatun.hb@gmail.com; phone:+90 322334 0055) \\ (Received $30^{\text {th }}$ Dec 2018; accepted $27^{\text {th }}$ Feb 2019)
}

\begin{abstract}
This study was carried out under field conditions to determine the effects of foliar urea, potassium sulphate $\left(\mathrm{K}_{2} \mathrm{SO}_{4}\right)$ and zinc sulphate heptahydrate $\left(\mathrm{ZnSO}_{4} .7 \mathrm{H}_{2} \mathrm{O}\right)$ treatments at vegetative and generative periods on yield, technological quality and mineral element concentrations of wheat (Triticum aestivum L. cv. Altinbasak). Experiments were conducted in two experiment groups (foliar treatments of $0 \%$ (Control); $0.5 \%$ Urea; $1 \%$ Urea; $0.5 \% \mathrm{ZnSO}_{4} .7 \mathrm{H}_{2} \mathrm{O} ; 0.5 \%$ Urea+0.5\% $\mathrm{ZnSO}_{4} .7 \mathrm{H}_{2} \mathrm{O}$; $1 \%$ Urea $+0.5 \% \mathrm{ZnSO}_{4} .7 \mathrm{H}_{2} \mathrm{O} ; 0.5 \% \mathrm{~K}_{2} \mathrm{SO}_{4}$ and $1 \% \mathrm{~K}_{2} \mathrm{SO}_{4}$ were performed in the first experiment and foliar $0 \% ; 0.5 \%$ Urea+0.5\% $\mathrm{K}_{2} \mathrm{SO}_{4} ; 0.5 \%$ Urea+1\% $\mathrm{K}_{2} \mathrm{SO}_{4} ; 1 \%$ Urea+0.5\% $\mathrm{K}_{2} \mathrm{SO}_{4} ; 1 \%$ Urea+1\% $\mathrm{K}_{2} \mathrm{SO}_{4}$ were performed in the second experiment). All treatments increased yield and sedimentation values as compared to the control treatments. In the first experiment, $0.5 \%$ urea treatment was prominent for yield, nitrogen and protein and urea $+\mathrm{ZnSO}_{4} .7 \mathrm{H}_{2} \mathrm{O}$ treatments for grain zinc and iron concentrations. In the second experiment, $1 \%$ urea $+0.5 \% \quad \mathrm{~K}_{2} \mathrm{SO}_{4}$ treatments were prominent for protein and grain nitrogen concentrations and $1 \%$ urea $+1 \% \mathrm{~K}_{2} \mathrm{SO}_{4}$ and $0.5 \%$ urea $+0.5 \% \mathrm{~K}_{2} \mathrm{SO}_{4}$ treatments for yield.
\end{abstract}

Keywords: nitrogen, sulphur, micronutrients, gluten, Zeleny sedimentation

\section{Introduction}

Cereals are staple foods, and are significant sources of nutrients in both developed and developing countries. Therefore, nutritional quality of cereals should be improved. Foliar fertilization seems to be a practical way to eliminate nutritional problems and to improve product quality. In this sense, foliar nitrogen $(\mathrm{N})$ treatments had significant effects on yield and quality parameters (Shah et al., 2003; Rahman et al., 2014). Especially, foliar application of urea was demonstrated to be an efficient method of $\mathrm{N}$ fertilization in grain cereals in 1950's (Finney et al., 1957). Foliar applications of potassium (K) (Hamouda et al., 2015) and zinc (Zn) (Habib, 2009) had also positive effects on grain yield and quality of wheat. It was recommended by Wang et al. (2017) that foliar $\mathrm{N}$ and $\mathrm{K}$ treatments could be used to maximize plant respond to $\mathrm{Zn}$ treatments.

Prevention of sulphur (S) release to atmosphere with environmental measures, highcost and resultant decreasing uses of $S$ fertilizers, again decreasing uses of S-containing $\mathrm{N}$ and phosphorus $(\mathrm{P})$ fertilizers, excessive nitrogenous fertilizer uses, breeding of high yield varieties and similar factors have made $S$ deficiency in soils and plants a widespread problem. Insufficient $S$ levels prevent grain cereals from reaching their actual potential in yield, quality and protein content. Insufficient $S$ also hinders efficient use of $\mathrm{N}$ applied to soils (Sahota, 2006). It was reported that $\mathrm{N}$ and $\mathrm{S}$ nutrition had significant effects on grain yield and protein concentration of wheat. Wheat $S$ need is less than $\mathrm{N}$ need. However, in sulphur deficiency, non-protein $\mathrm{N}$ compounds (free amides: asparagine, glutamine) are accumulated, and synthesis and accumulation of S-containing amino acids (cysteine, methionine) in grains decreased (Zhao et al., 1999a; 
Granvogl et al., 2007). Under $\mathrm{S}$ deficiency, these $\mathrm{N}$ forms increase and signal is passed from the shoots to roots as if there was sufficient $\mathrm{N}$, thus less $\mathrm{N}$ is up taken by the plants from the nutrient ambient. When the plants are nourished with sufficient $\mathrm{S}$, protein $\mathrm{N}$, organic $\mathrm{S}$ and $\mathrm{SO}_{4}-\mathrm{S}$ concentrations increase, but nitrate and soluble organic acid concentrations decrease (Marschner, 1995). Such findings revealed that S-deficiency destroyed plant $\mathrm{N}$ metabolism (McGrath and Zhao, 1996). Nitrogen and S are the basic components of proteins, therefore a balance between $\mathrm{N}$ and $\mathrm{S}$ is a critical issue for bread making quality of wheat (Randall and Wrigley, 1986). Sulphur not only influences N use and protein quality, but also plays a significant role in baking quality (Ryant and Hřivna, 2004).

Recent studies revealed that cereal grains were poor in mineral element concentrations. For instance, $\mathrm{Zn}$ concentrations of wheat grains (generally $25-30 \mathrm{mg} \mathrm{kg}^{-1}$ ) were quite below the requirements for healthy human nutrition or the recommended levels (Erdal et al., 2002; Cakmak, 2008). Previous studies also indicated that grain $\mathrm{Zn}$ and Fe concentrations could be improved with $\mathrm{N}$ treatments, and $\mathrm{Zn}$ and $\mathrm{N}$ treatments had a synergic effect in increasing $\mathrm{Zn}$ concentrations of wheat grains (Kutman, 2010; Shi et al., 2010). In another study, increasing Zn and Fe concentrations of wheat grains grown under field conditions were reported with increasing $\mathrm{N}$ treatments (Cakmak et al., 2010). When the sufficient $\mathrm{Zn}$ levels were supplied to plants, both soil and foliar $\mathrm{N}$ treatments were reported to increase grain $\mathrm{Zn}$ concentrations (Kutman et al., 2010). Analyses for grain mineral nutrient concentrations revealed that there were significant correlations between grain $\mathrm{Zn}$ and $\mathrm{Fe}$ concentrations and $\mathrm{S}$ concentrations (McDonald and Mousavvi, 2009).

The objective of the present study was to evaluate the effects of urea, $\mathrm{K}_{2} \mathrm{SO}_{4}$ and $\mathrm{ZnSO}_{4} .7 \mathrm{H}_{2} \mathrm{O}$ treatments on yield parameters, technological quality and grain nutrient concentrations of Altinbasak bread wheat cultivar.

\section{Materials and methods}

\section{Seed and soil materials}

Altinbasak bread wheat cultivar commonly grown in Çukurova region was used as the seed material of the present study. Field experiments were conducted over the experimental fields of Eastern Mediterranean Agricultural Research Institute. Experiments were carried out at Dogankent station (36 $\left.85^{\prime} \mathrm{N}, 35^{\circ} 34^{\prime} \mathrm{E}\right)$ during the wheat growing seasons of the years 2014-2015 and 2015-2016. Soil physical and chemical characteristics of the experimental site are provided in Table 1.

Table 1. Soil physical and chemical characteristics of the experiment site for 2014-2015 and 2015-2016 growing seasons

\begin{tabular}{|c|c|c|c|c|c|c|c|c|c|c|c|c|}
\hline $\begin{array}{l}\text { Growing } \\
\text { Season }\end{array}$ & Texture & pH & Salinity & $\mathrm{CaCO}_{3}$ & Org.M. & $\mathbf{P}$ & $\mathbf{K}$ & $\mathrm{SO}_{4-S}$ & $\mathbf{Z n}$ & $\mathbf{F e}$ & $\mathbf{C u}$ & Mn \\
\hline & & $(1: 2.5)$ & $\begin{array}{c}(\mathrm{mmhos} \\
\left.\mathrm{cm}^{-1}\right)\end{array}$ & \multicolumn{2}{|c|}{$\%$} & \multicolumn{7}{|c|}{$\left(\mathrm{mg} \mathrm{kg}^{-1}\right)$} \\
\hline 2014-15 & CL & 7.85 & 0.25 & 15.2 & 1.45 & 5.60 & 426 & 10.2 & 0.35 & 4.60 & 2.30 & 4.81 \\
\hline $2015-16$ & CL & 8.01 & 0.02 & 14.2 & 1.50 & 4.95 & 310 & 11.2 & 0.36 & 4.76 & 0.67 & 2.57 \\
\hline
\end{tabular}

CL: clay-loam 


\section{Field experiments}

Experiments were conducted in randomized blocks - split plots experimental design with 4 replications. Experiments were set up on 7 November 2014 in the first year and on 14 November 2015 in the second year. Treatment periods (before flowering - BF, after flowering - AF) were placed in the main plots and foliar treatments were placed in sub-plots $\left(1.4 \times 5=7 \mathrm{~m}^{2}\right)$. Sowing density was arranged as 450 seed per $\mathrm{m}^{2}$. At sowing, $70 \mathrm{~kg} \mathrm{ha}^{-1}$ phosphorus and $160 \mathrm{~kg} \mathrm{ha}^{-1}$ nitrogen fertilizers were also applied (in DAP and urea forms). Nitrogen was applied at sowing and tillering stages. Weed control was practiced at tillering stage with $200 \mathrm{ml} \mathrm{ha}^{-1}$ Terdok $240 \mathrm{EC}$. At the end of tillering period, 2-4 D Amine was applied against broad-leaf weeds.

Before flowering (BF) period; foliar treatments were performed once at stem elongation stage (Zadoks 34-36) and once at booting stage (Zadoks 47-49). After flowering period; foliar treatments were performed once at early milk stage (Zadoks 73-74) and once at early dough stage (Zadoks 83-84) (Zadoks et al., 1974). Any surfactant was not used in the fertilizer solutions (w/v). Generally, a typical foliar Zn fertilizer solution contains $2-5 \mathrm{~g}$ zinc sulphate heptahydrate $\left(\mathrm{ZnSO}_{4} .7 \mathrm{H}_{2} \mathrm{O}\right)$ per liter (Cakmak and Kutman, 2018). In present study, foliar treatments of the first experiment were: $0 \%$ (Control); $0.5 \%$ Urea; $1 \%$ Urea; $0.5 \% \quad \mathrm{ZnSO}_{4} .7 \mathrm{H}_{2} \mathrm{O} ; 0.5 \%$ Urea+0.5\% $\mathrm{ZnSO}_{4} .7 \mathrm{H}_{2} \mathrm{O} ; 1 \%$ Urea+0.5\% $\quad \mathrm{ZnSO}_{4} .7 \mathrm{H}_{2} \mathrm{O} ; 0.5 \% \quad \mathrm{~K}_{2} \mathrm{SO}_{4}$ and $1 \% \mathrm{~K}_{2} \mathrm{SO}_{4}$. Foliar treatments of the second experiment were: $0 \%$ (Control); $0.5 \%$ Urea+ $0.5 \% \quad \mathrm{~K}_{2} \mathrm{SO}_{4}$; $0.5 \%$ Urea+1\% $\mathrm{K}_{2} \mathrm{SO}_{4} ; 1 \%$ Urea+0.5\% $\mathrm{K}_{2} \mathrm{SO}_{4} ; 1 \%$ Urea+ $1 \% \mathrm{~K}_{2} \mathrm{SO}_{4}$. Only water was applied to control plots. In the other plots, $1000 \mathrm{ml}$ solution was used for each one of $7 \mathrm{~m}^{2}$ plots as to homogeneously wet the entire plot at stem elongation and booting stages before flowering and at early milk and early dough stages after flowering.

Plots were harvested by a combine, and total grain yield was expressed in $\mathrm{kg}$ per hectare at $11 \%$ moisture basis. Harvest date was 29 May 2015 in the first year and 13 June 2016 in the second year. Following harvests from $5 \mathrm{~m} \times 1.4 \mathrm{~m}\left(7 \mathrm{~m}^{2}\right)$ plots, grain yields per hectare were determined. The 1000-grain weights were determined in accordance with Ozkaya and Ozkaya (2005). Grain samples were ground and wetdigested in a microwave digester using $2 \mathrm{ml}$ of $35 \% \mathrm{H}_{2} \mathrm{O}_{2}$ and $5 \mathrm{ml}$ of $65 \% \mathrm{HNO}_{3}$. After the digestion, $\mathrm{K}, \mathrm{S}, \mathrm{Zn}$ and $\mathrm{Fe}$ were analyzed by an inductively coupled plasma optical emission spectrometer (ICP-OES; Varian-Vista Pro). LECO TruSpec C/N Analyzer (Leco Corp. St Joseph, MI, USA) operating in accordance with Dumas method was used to determine nitrogen concentrations. Reference leaf samples from National Institute of Standards and Technology (Gaithersburg, MD, USA) were used to check the related element ( $\mathrm{S}, \mathrm{K}, \mathrm{Zn}$ and $\mathrm{Fe}$ ) measurements. Total protein concentration of the grain was calculated as $5.7 \times \mathrm{N}$ concentration (Zhao et al., 1999b). Wet gluten concentration was measured in a FOSS NIRS 6500 System according to standard method ICC 155 (International Association for Cereal Chemistry, 1994). Zeleny sedimentation was determined by using ICC method 116/1 (International Association for Cereal Chemistry, 1994).

\section{Soil analysis}

Available soil $\mathrm{Zn}, \mathrm{Fe}$, manganese $(\mathrm{Mn})$ and copper $(\mathrm{Cu})$ concentrations were determined according to Lindsay and Norvel (1978), available P concentration in accordance with Olsen et al. (1954). Soil K concentrations were measured in accordance with the ammonium acetate (pH: 7, 1N) method of Carson (1980). Soil pH was detected 
according to Jackson (1959). Soil organic matter content was determined following the Walkey-Black wet-etching method (Jackson, 1959). Soil texture was determined according to Bouyoucus (1951). Soil lime content was determined according to Allison and Moodie (1965) and soil salinity was determined from saturation paste extracts according to Wheatstone bridge method (U. S. Salinity Laboratory Staff, 1954). For soil soluble $\mathrm{SO}_{4}-\mathrm{S}$ analyses, dried and sieved $(<0.18 \mathrm{~mm}) 5 \mathrm{~g}$ soil sample was placed into $250 \mathrm{ml}$ Erlenmeyer flasks, supplemented with $50 \mathrm{ml} 0.1 \mathrm{M} \mathrm{LiCI}$ solution and shaken for 30 minutes. Soil suspension was then filtered through filter papers and resultant extract was read at $182.037 \mathrm{~nm}$ wave length of an ICP device for soluble $\mathrm{SO}_{4}-\mathrm{S}$ quantity (Arkley, 1961).

\section{Weather conditions}

A total of $687 \mathrm{~mm}$ rainfall was received in the 2014-2015 growing season and $348 \mathrm{~mm}$ in the 2015-2016 growing season. While the precipitations of the first year were above the long-term averages (about $25 \%$ greater than the averages), precipitations of the second year were quite below the long-term averages (about 38\% less than the averages). Temperatures of the experimental years were close to long-term averages (Table 2).

Table 2. Weather conditions of experimental site for 2014-2015 and 2015-2016 growing seasons and long-term averages (1978-2016)

\begin{tabular}{|c|c|c|c|c|c|c|c|c|c|c|}
\hline Parameters & Time & $\begin{array}{l}\text { Nov. } \\
2014\end{array}$ & $\begin{array}{l}\text { Dec. } \\
2014\end{array}$ & $\begin{array}{l}\text { Jan. } \\
2015\end{array}$ & $\begin{array}{l}\text { Feb. } \\
2015\end{array}$ & $\begin{array}{l}\text { Mar. } \\
2015\end{array}$ & $\begin{array}{l}\text { Apr. } \\
2015\end{array}$ & $\begin{array}{l}\text { May } \\
2015\end{array}$ & $\begin{array}{l}\text { Jun. } \\
2015\end{array}$ & Total \\
\hline \multirow{2}{*}{ Rainfall (mm) } & Long & 86.3 & 115.6 & 97.4 & 80.7 & 60.5 & 47.7 & 43.8 & 16.8 & 549 \\
\hline & 2014-2015 & 72.5 & 102.5 & 153.0 & 160.0 & 91.0 & 19.0 & 58.0 & 30.5 & 687 \\
\hline \multirow{2}{*}{$\begin{array}{c}\text { Temperature } \\
\left({ }^{\circ} \mathrm{C}\right)\end{array}$} & Long-term & 14.7 & 10.4 & 9.3 & 9.9 & 12.8 & 17.3 & 21.5 & 25.3 & \\
\hline & 2014-2015 & 15.0 & 13.0 & 9.0 & 11.0 & 14.0 & 16.0 & 22.0 & 24.0 & \\
\hline & & $\begin{array}{l}\text { Nov. } \\
2015\end{array}$ & $\begin{array}{l}\text { Dec. } \\
2015\end{array}$ & $\begin{array}{l}\text { Jan. } \\
2016\end{array}$ & $\begin{array}{l}\text { Feb. } \\
2016\end{array}$ & $\begin{array}{l}\text { Mar. } \\
2016\end{array}$ & $\begin{array}{l}\text { Apr. } \\
2016\end{array}$ & $\begin{array}{l}\text { May } \\
2016\end{array}$ & $\begin{array}{l}\text { Jun. } \\
2016\end{array}$ & Total \\
\hline \multirow{2}{*}{ Rainfall (mm) } & Long term & 86.3 & 115.6 & 97.4 & 80.7 & 60.5 & 47.7 & 43.8 & 16.8 & 549 \\
\hline & $2015-2016$ & 0.0 & 0.0 & 105.0 & 64.0 & 98.0 & 5.0 & 71.0 & 5.0 & 348 \\
\hline \multirow{2}{*}{$\begin{array}{c}\text { Temperature } \\
\left({ }^{\circ} \mathrm{C}\right)\end{array}$} & Long term & 14.7 & 10.4 & 9.3 & 9.9 & 12.8 & 17.3 & 21.5 & 25.3 & \\
\hline & $2015-2016$ & 13.1 & 9.1 & 7.3 & 12.3 & 14.0 & 18.5 & 19.8 & 23.0 & \\
\hline
\end{tabular}

\section{Statistical analysis}

JUMP software was used for statistical analyses. Following ANOVA, significant factor means were compared by TUKEY's multiple range tests. The significance levels were taken as $\mathrm{P}<0.05(*)$ and $\mathrm{P}<0.01(* *)$.

\section{Results and discussion}

Effects of treatments on grain yield, 1000-grain weight, protein, wet gluten and Zeleny sedimentation

There were significant differences in the yields of the years because of climate factors (Table 3). Rainfalls and temperatures are the most significant climate factors influencing plant growth and development. Total precipitations of the second year (348 $\mathrm{mm})$ were quite lower than the precipitations of the first year $(687 \mathrm{~mm})$ (Table 2). 
Table 3. Analysis of variance for investigated parameters

\begin{tabular}{|c|c|c|c|c|c|c|c|c|c|c|c|}
\hline Source of variation & d.f. & Grain Yield & $\begin{array}{l}1000 \text { Grain } \\
\text { Weight }\end{array}$ & Protein & Wet Gluten & Zeleny Sed. & Grain N & Grain K & Grain S & Grain Zn & Grain Fe \\
\hline \multicolumn{12}{|c|}{$I^{s t}$ Experiment } \\
\hline Year (A) & 1 & $<.0001 * *$ & $<.0001 * *$ & $<.0001 * *$ & 0.0555 & $0.0015 * *$ & $<.0001 * *$ & $<.0001 * *$ & $0.0054 * *$ & $0.0048 * *$ & $0.0114^{*}$ \\
\hline Error 1 & 6 & 0.4507 & 0.9987 & 0.7636 & 0.9012 & 0.7267 & 0.7672 & 0.5821 & 0.9405 & 0.6595 & 0.9987 \\
\hline Application Time (B) & 1 & $0.5819 \mathrm{~ns}$ & $0.7290 \mathrm{~ns}$ & $0.3378 \mathrm{~ns}$ & $0.6061 \mathrm{~ns}$ & $0.8653 \mathrm{~ns}$ & $0.3407 \mathrm{~ns}$ & $0.2529 \mathrm{~ns}$ & $0.3918 \mathrm{~ns}$ & $0.6281 \mathrm{~ns}$ & $0.8007 \mathrm{~ns}$ \\
\hline $\mathrm{A} \times \mathrm{B}$ & 1 & $0.9842 \mathrm{~ns}$ & $0.7237 \mathrm{~ns}$ & $0.5931 \mathrm{~ns}$ & $0.3854 \mathrm{~ns}$ & $0.4843 \mathrm{~ns}$ & $0.5926 \mathrm{~ns}$ & $0.8254 \mathrm{~ns}$ & $0.9394 \mathrm{~ns}$ & $0.7842 \mathrm{~ns}$ & $0.9800 \mathrm{~ns}$ \\
\hline Error 2 & 6 & 0.0105 & $<.0001$ & 0.0564 & $<.0001$ & 0.3030 & 0.0552 & 0.5931 & $<.0001$ & 0.0071 & $<.0001$ \\
\hline Applications (C) & 7 & $0.0041^{* *}$ & $0.8750 \mathrm{~ns}$ & $<.0001 * *$ & $0.0507 \mathrm{~ns}$ & $0.0205 *$ & $<.0001^{* *}$ & $0.0068 * *$ & $0.0615 \mathrm{~ns}$ & $<.0001 * *$ & $0.0020 * *$ \\
\hline $\mathrm{A} \times \mathrm{C}$ & 7 & $0.0921 \mathrm{~ns}$ & $0.7622 \mathrm{~ns}$ & $0.0055 * *$ & $0.1209 \mathrm{~ns}$ & $0.2446 \mathrm{~ns}$ & $0.0053 * *$ & $0.9935 \mathrm{~ns}$ & $0.2177 \mathrm{~ns}$ & $0.2241 \mathrm{~ns}$ & $0.1259 \mathrm{~ns}$ \\
\hline $\mathrm{B} \times \mathrm{C}$ & 7 & $0.0020 * *$ & $0.7639 \mathrm{~ns}$ & $0.0898 \mathrm{~ns}$ & $0.0191 *$ & $0.1328 \mathrm{~ns}$ & $0.0867 \mathrm{~ns}$ & $0.7819 \mathrm{~ns}$ & $0.1521 \mathrm{~ns}$ & $0.5063 \mathrm{~ns}$ & $0.4446 \mathrm{~ns}$ \\
\hline$A \times B \times C$ & 7 & $0.9795 \mathrm{~ns}$ & $0.5557 \mathrm{~ns}$ & $0.0003 * *$ & $0.2436 \mathrm{~ns}$ & $0.3321 \mathrm{~ns}$ & $0.0003 * *$ & $0.9989 \mathrm{~ns}$ & $0.4522 \mathrm{~ns}$ & $0.0020 * *$ & $0.8867 \mathrm{~ns}$ \\
\hline General & 84 & & & & & & & & & & \\
\hline C. Total & 127 & & & & & & & & & & \\
\hline \multicolumn{12}{|c|}{$I^{\text {nd }}$ Experiment } \\
\hline Year (A) & 1 & $<.0001 * *$ & $0.0042 * *$ & $0.0031 * *$ & $0.0814 \mathrm{~ns}$ & $0.0026^{* *}$ & $0.0030 * *$ & $<.0001^{* *}$ & $0.0011 * *$ & $<.0001 * *$ & $0.0006^{* *}$ \\
\hline Error 1 & 6 & 0.8896 & 0.6189 & 0.3242 & 0.7276 & 0.9771 & 0.3218 & 0.0129 & 0.796 & 0.4032 & 0.9991 \\
\hline Application Time (B) & 1 & $0.6087 \mathrm{~ns}$ & $0.4619 \mathrm{~ns}$ & $0.0746 \mathrm{~ns}$ & $0.2460 \mathrm{~ns}$ & $0.2698 \mathrm{~ns}$ & $0.0718 \mathrm{~ns}$ & $0.3427 \mathrm{~ns}$ & $0.3155 \mathrm{~ns}$ & $0.2919 \mathrm{~ns}$ & $0.3185 \mathrm{~ns}$ \\
\hline $\mathrm{A} \times \mathrm{B}$ & 1 & $0.2722 \mathrm{~ns}$ & $0.4599 \mathrm{~ns}$ & $0.0411^{*}$ & $0.4927 \mathrm{~ns}$ & $0.7885 \mathrm{~ns}$ & $0.0420 *$ & $0.6947 \mathrm{~ns}$ & $0.5212 \mathrm{~ns}$ & $0.5940 \mathrm{~ns}$ & $0.4196 \mathrm{~ns}$ \\
\hline Error 2 & 6 & 0.0235 & $<.0001$ & 0.0178 & 0.0002 & 0.0143 & 0.0182 & 0.8969 & 0.0131 & 0.7854 & 0.0013 \\
\hline Applications (C) & 4 & $0.0335 *$ & $0.2004 \mathrm{~ns}$ & $0.0002 * *$ & $0.2359 \mathrm{~ns}$ & $<.0001 * *$ & $0.0002 * *$ & $0.1854 \mathrm{~ns}$ & $0.1817 \mathrm{~ns}$ & $0.0463 *$ & $0.3065 \mathrm{~ns}$ \\
\hline $\mathrm{A} \times \mathrm{C}$ & 4 & $<.0001 * *$ & $0.3736 \mathrm{~ns}$ & $0.0154^{*}$ & $0.0301 *$ & $0.9519 \mathrm{~ns}$ & $0.0150 *$ & $0.9801 \mathrm{~ns}$ & $0.8747 \mathrm{~ns}$ & $0.2447 \mathrm{~ns}$ & $0.0718 \mathrm{~ns}$ \\
\hline $\mathrm{B} \times \mathrm{C}$ & 4 & $0.3588 \mathrm{~ns}$ & $0.6439 \mathrm{~ns}$ & $0.1211 \mathrm{~ns}$ & $0.6182 \mathrm{~ns}$ & $0.2951 \mathrm{~ns}$ & $0.1236 \mathrm{~ns}$ & $0.2147 \mathrm{~ns}$ & $0.9896 \mathrm{~ns}$ & $0.3313 \mathrm{~ns}$ & $0.1020 \mathrm{~ns}$ \\
\hline$A \times B \times C$ & 4 & $0.7770 \mathrm{~ns}$ & $0.6757 \mathrm{~ns}$ & $0.5963 \mathrm{~ns}$ & $0.1620 \mathrm{~ns}$ & $0.5572 \mathrm{~ns}$ & $0.6122 \mathrm{~ns}$ & $0.9950 \mathrm{~ns}$ & $0.2286 \mathrm{~ns}$ & $0.2415 \mathrm{~ns}$ & $0.1291 \mathrm{~ns}$ \\
\hline General & 48 & & & & & & & & & & \\
\hline C. Total & 79 & & & & & & & & & & \\
\hline
\end{tabular}

$*: \mathrm{p}<0.05 ; * *: \mathrm{p}<0.01 ; \mathrm{NS}$ : not significant 
Therefore, yields of the second year were lower than the yields of the first year in both experiments (Table 4). Considering the treatment periods, the differences in yields of before flowering (BF) and after flowering (AF) periods were not significantly different (Table 4).

In the first experiment, effects of treatments on yields were found to be significant (Table 3). With regard to general averages of treatments, yields of $0.5 \%$ Urea+0.5\% $\mathrm{ZnSO}_{4} .7 \mathrm{H}_{2} \mathrm{O}$ and $0.5 \% \mathrm{ZnSO}_{4} .7 \mathrm{H}_{2} \mathrm{O}$ treatments were placed in the same statistical group with the control treatment (Table 5). The greatest yield $\left(974 \mathrm{~kg} \mathrm{da}^{-1}\right)$ was obtained from $0.5 \%$ Urea treatments (Table 5). Jakhro et al. (2000) reported that urea treatments increased plant height, number of tillers, spike lengths, harvest index, grain yield, hay yield and protein content of wheat grains. Khan et al. (2009) applied 4\% urea at 6 different concentrations and at consecutive 3 stages (tillering, stem elongation and booting) and reported $32 \%$ increase in wheat grain yield. Considering the general averages of treatments of the first experiment, it was observed that foliar zinc treatments did not result in significant differences in yields. Foliar urea and zinc combined treatment $\left(1 \%\right.$ Urea+0.5\% $\left.\mathrm{ZnSO}_{4} .7 \mathrm{H}_{2} \mathrm{O}\right)$ slightly increased yields as compared to the control treatment (Table 5). With regard to general averages of the treatments of the second trails, $0.5 \%$ Urea+0.5\% $\mathrm{K}_{2} \mathrm{SO}_{4}$ and $1 \%$ Urea+1\% $\mathrm{K}_{2} \mathrm{SO}_{4}$ treatments resulted in significant increases in yields as compared to the control treatments (Table 5). In the first experiment, foliar $\mathrm{K}_{2} \mathrm{SO}_{4}$ treatments $\left(0.5 \% \mathrm{~K}_{2} \mathrm{SO}_{4}, 1 \% \mathrm{~K}_{2} \mathrm{SO}_{4}\right)$ before flowering slightly increased grain yields as compared to the control treatment (Table 5). Such a positive impact probably resulted from both $\mathrm{K}$ and $\mathrm{S}$. Thusly, foliar potassium treatments had positive effects on physiological parameters especially in grain-fill period (Zareian et al., 2013) and yield values (Hamouda et al., 2015). Similarly, Gupta et al. (2004) reported significant increases in yield and yield components with $S$ treatments. It was reported in a study carried out in Germany, yield increase rates improved by $17 \%$ with $\mathrm{S}$ treatments and the yield increase supplied by $\mathrm{S}$ treatments varied between 5-30\% (Zhao et al., 2002). Zinc sulphate and $\mathrm{K}_{2} \mathrm{SO}_{4}$ sources are commonly preferred in foliar fertilization practices (Singh et al., 2013).

While the treatments did not result in significant differences in 1000-grain weights of the first and second experiments, years created significant differences (Table 3). In the first experiment, 1000-grain weight of the first year $(45.8 \mathrm{~g})$ was greater than the second year $(33.9 \mathrm{~g})$. Similar decrease trends were also observed in the second experiment (Table 4). The differences between the treatment periods (BF and AF) were not found to be significant in both experiments (Table 3). General averages of 1000-grain weights in before and after flowering periods were not significant in both experiments (Table 5).

In the first experiment, treatments resulted in significant differences in grain protein concentrations of both periods. The highest protein concentration was found in the second year with $1 \%$ urea application of BF period. Together with decreasing 1000grain weights, grain protein concentrations increased in the second year (concentration effect) as compared to the first year. Similar findings were also observed in the second experiment (Table 4). With regard to averages of treatments, the greatest grain protein concentration in the first experiment was obtained from $0.5 \%$ urea treatment $(12.9 \%)$ and the lowest value was observed in control treatment (12.1\%) (Table 5). In the first experiment, as the averages of treatments, all treatments increased grain protein concentrations as compared to the control treatments (Table 5). 
Table 4. Effects of different foliar fertilizer treatments, applied before and after flowering, on grain yield, 1000-grain weight and protein content of Altınbaşak bread wheat cultivar

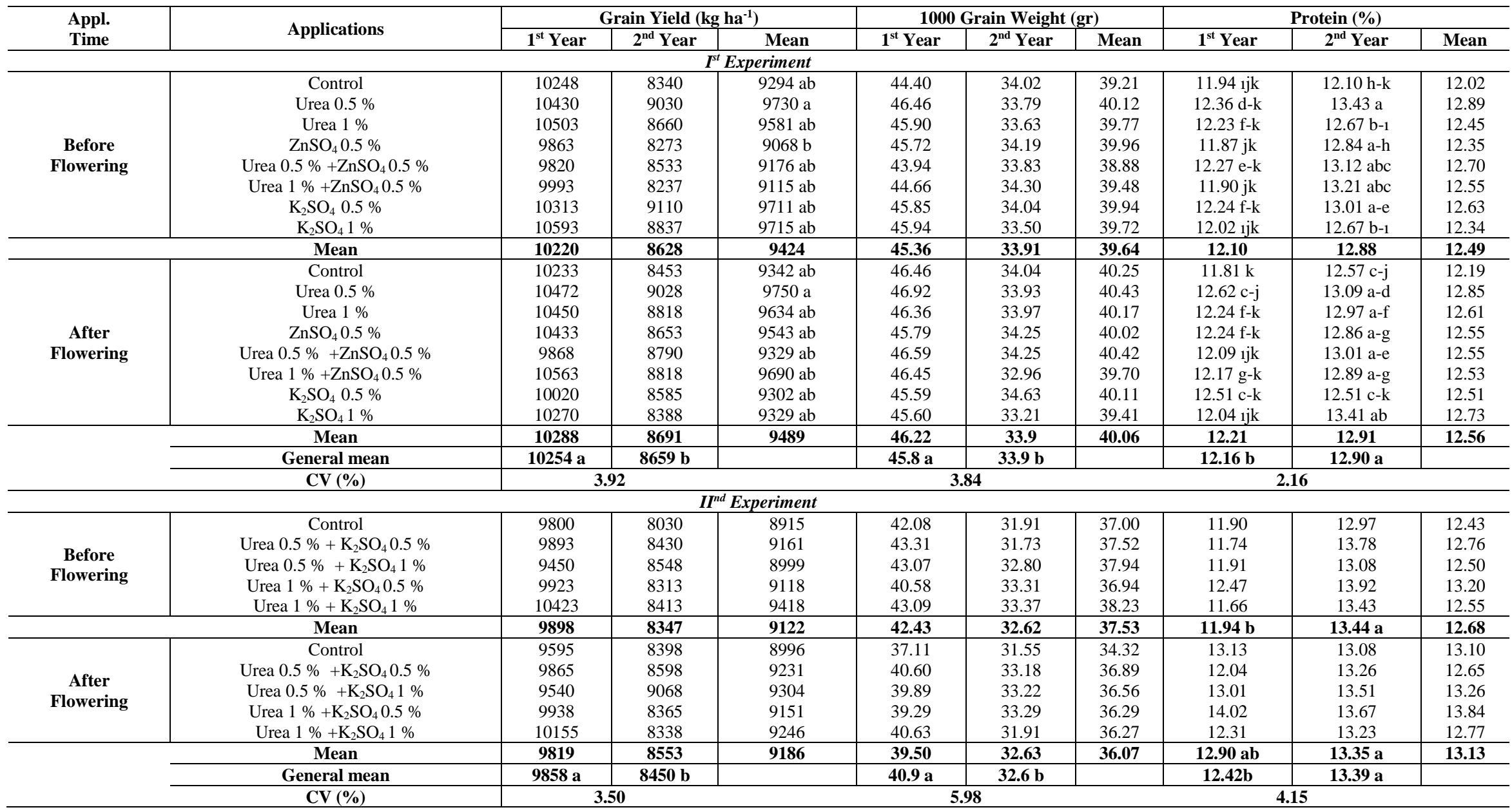


Table 5. Effects of different foliar fertilizer treatments and combinations on general mean of grain yield, 1000-grain weight, protein, wet gluten and Zeleny sedimentation of Altınbaşak bread wheat cultivar

\begin{tabular}{|c|c|c|c|c|c|c|}
\hline & \multirow{3}{*}{ Applications } & \multicolumn{5}{|c|}{ General Mean } \\
\hline & & \multirow{2}{*}{$\begin{array}{c}\text { Grain Yield } \\
\left(\mathrm{kg} \mathrm{ha}^{-1}\right)\end{array}$} & \multirow{2}{*}{$\frac{1000 \text { G. Wt. }}{\text { (g) }}$} & Protein & Wet Glu. & \multirow{2}{*}{$\begin{array}{c}\text { Zeleny Sed. } \\
(\mathrm{ml})\end{array}$} \\
\hline & & & & \multicolumn{2}{|c|}{$(\%)$} & \\
\hline \multirow{8}{*}{$\begin{array}{c}\text { Ist }^{\text {st }} \\
\text { Experiment }\end{array}$} & Control & $9318 \mathrm{~b}$ & 39.7 & $12.1 \mathrm{c}$ & 25.6 & $50.1 \mathrm{~b}$ \\
\hline & Urea $0.5 \%$ & 9740 a & 40.3 & $12.9 \mathrm{a}$ & 26.7 & $54.6 \mathrm{ab}$ \\
\hline & Urea $1 \%$ & $9607 \mathrm{ab}$ & 40.0 & $12.5 \mathrm{~b}$ & 26.7 & $55.6 \mathrm{a}$ \\
\hline & $\mathrm{ZnSO}_{4} 0.5 \%$ & $9305 \mathrm{~b}$ & 40.0 & $12.5 \mathrm{~b}$ & 25.6 & $52.7 \mathrm{ab}$ \\
\hline & Urea $0.5 \%+\mathrm{ZnSO}_{4} 0.5 \%$ & $9253 \mathrm{~b}$ & 39.7 & $12.6 \mathrm{ab}$ & 26.6 & $54.1 \mathrm{ab}$ \\
\hline & Urea $1 \%+\mathrm{ZnSO}_{4} 0.5 \%$ & $9403 \mathrm{ab}$ & 39.6 & $12.5 \mathrm{~b}$ & 26.2 & $55.1 \mathrm{ab}$ \\
\hline & $\mathrm{K}_{2} \mathrm{SO}_{4} 0.5 \%$ & $9507 \mathrm{ab}$ & 40.0 & $12.6 \mathrm{~b}$ & 26.5 & $55.7 \mathrm{a}$ \\
\hline & $\mathrm{K}_{2} \mathrm{SO}_{4} 1 \%$ & $9522 \mathrm{ab}$ & 39.6 & $12.5 \mathrm{~b}$ & 26.1 & $55.5 \mathrm{a}$ \\
\hline \multirow{5}{*}{$\begin{array}{c}\text { II } \\
\text { Experiment }\end{array}$} & Control & $8956 \mathrm{~b}$ & 35.7 & $12.8 \mathrm{~b}$ & 27.7 & $48.5 \mathrm{~b}$ \\
\hline & Urea $0.5 \%+\mathrm{K}_{2} \mathrm{SO}_{4} 0.5 \%$ & 9196 a & 37.2 & $12.8 \mathrm{~b}$ & 27.3 & $56.5 \mathrm{a}$ \\
\hline & Urea $0.5 \%+\mathrm{K}_{2} \mathrm{SO}_{4} 1 \%$ & $9151 \mathrm{ab}$ & 37.3 & $12.9 \mathrm{~b}$ & 27.7 & $54.5 \mathrm{a}$ \\
\hline & Urea $1 \%+\mathrm{K}_{2} \mathrm{SO}_{4} 0.5 \%$ & $9134 \mathrm{ab}$ & 36.6 & $13.5 \mathrm{a}$ & 29.0 & $59.5 \mathrm{a}$ \\
\hline & Urea $1 \%+\mathrm{K}_{2} \mathrm{SO}_{4} 1 \%$ & $9332 \mathrm{a}$ & 37.3 & $12.7 \mathrm{~b}$ & 27.8 & $56.8 \mathrm{a}$ \\
\hline
\end{tabular}

In the second experiment, the greatest grain protein concentration was obtained from $1 \%$ Urea $+0.5 \% \mathrm{~K}_{2} \mathrm{SO}_{4}$ treatments $(13.5 \%)$ and the other treatments had similar protein concentrations with the control treatments (Table 5). Present protein concentrations (Table 4) were all within 11-14\% limit values specified by Mailhot and Patton (1988) for bread making. Grain protein concentrations of the 23 bread wheat genotypes varied between 7.99-13.31\% (Soboka et al., 2017).

In the first experiment, the greatest wet gluten concentration (27.09\%) was obtained from $1 \%$ urea treatment of AF period (Table 6). Similarly, increasing wet gluten levels were reported with increasing nitrogen doses (Erekul et al., 2012). In present study, the lowest wet gluten concentration $(24.85 \%)$ was obtained from $0.5 \% \mathrm{ZnSO}_{4}$ treatment of $\mathrm{BF}$ period (Table 6). In the second experiment, wet gluten concentrations did not change with treatments (Table 6). In both experiments, greater wet gluten concentrations were observed in the second year, but the differences in wet gluten concentrations of the years were not significant (Table 6). Considering the general averages of the treatments, effects of treatments on wet gluten concentrations were not found to be significant in both experiments (Table 5).

The sedimentation values of the wheat cultivar in this research, characterizing the swelling capacity of gluten, exceeded the nominal value $(20 \mathrm{ml})$ for bread wheat in both years (Table 6). In both experiments, Zeleny sedimentation values of treatment periods were not found to be significant (Table 3), but the treatments were found to be significant (Table 3 and 5). In the first experiment, the greatest Zeleny sedimentation value was obtained from $1 \%$ Urea, $0.5 \% \mathrm{~K}_{2} \mathrm{SO}_{4}$ and $1 \% \mathrm{~K}_{2} \mathrm{SO}_{4}$ treatments and the lowest value was obtained from the control treatments (Table 5). Slightly greater Zeleny sedimentation values were observed from single $\mathrm{ZnSO}_{4} .7 \mathrm{H}_{2} \mathrm{O}$ and combined urea treatments as compared to the control treatment (Table 5). The increases in Zeleny sedimentation values with the separate urea and $\mathrm{K}_{2} \mathrm{SO}_{4}$ treatments of the first experiment as compared to the control treatments were also observed with urea and $\mathrm{K}_{2} \mathrm{SO}_{4}$ combined treatments of the second experiment (Table 5). Zeleny sedimentation 
values should be above $37 \mathrm{ml}$ for a quality bread making. The greater the values over this value, the greater the quality will be. While $43 \mathrm{ml}$ is assessed as moderately well, the values over $50 \mathrm{ml}$ were assessed as the $1^{\text {st }}$ Class wheat. In another study, Zeleny sedimentation $(\mathrm{ml})$ values were classified as; > $30 \mathrm{ml}$ very well; 25-30 ml well; 20-25 $\mathrm{ml}$ moderate and $<20 \mathrm{ml}$ poor (Unal, 2002). In present study, all treatments of both experiments yielded Zeleny sedimentation values above $50 \mathrm{ml}$ (Table 5).

It was reported in a previous study that urea treatments applied at flowering period significantly increased protein, Zeleny sedimentation and wet gluten values of bread wheat cultivars (Varga and Svečnjak, 2006). Late period urea treatments were also reported to increase protein and wet gluten contents of wheat cultivars (Peltonen, 1992).

Table 6. Effects of different foliar fertilizer treatments, applied before and after flowering, on wet gluten and Zeleny sedimentation of Altınbaşak bread wheat cultivar

\begin{tabular}{|c|c|c|c|c|c|c|c|}
\hline \multirow{2}{*}{$\begin{array}{l}\text { Appl. } \\
\text { Time }\end{array}$} & \multirow{2}{*}{ Applications } & \multicolumn{3}{|c|}{ Wet Gluten (\%) } & \multicolumn{3}{|c|}{ Zeleny Sedimentation (ml) } \\
\hline & & $1^{\text {st }}$ Year & $2^{\text {nd }}$ Year & Mean & $1^{\text {st }}$ Year & $2^{\text {nd }}$ Year & Mean \\
\hline \multicolumn{8}{|c|}{$I^{\text {st }}$ Experiment } \\
\hline \multirow{8}{*}{$\begin{array}{c}\text { Before } \\
\text { Flowering }\end{array}$} & Control & 25.83 & 25.85 & $25.84 \mathrm{ab}$ & 48.25 & 50.88 & 49.56 \\
\hline & Urea $0.5 \%$ & 25.34 & 27.69 & $26.51 \mathrm{ab}$ & 50.50 & 59.75 & 55.13 \\
\hline & Urea $1 \%$ & 26.10 & 26.46 & $26.28 \mathrm{ab}$ & 52.25 & 61.13 & 56.69 \\
\hline & $\mathrm{ZnSO}_{4} 0.5 \%$ & 24.28 & 25.41 & $24.85 \mathrm{~b}$ & 47.25 & 56.50 & 51.88 \\
\hline & Urea $0.5 \%+\mathrm{ZnSO}_{4} 0.5 \%$ & 25.72 & 27.80 & $26.76 \mathrm{ab}$ & 49.25 & 60.00 & 54.63 \\
\hline & Urea $1 \%+\mathrm{ZnSO}_{4} 0.5 \%$ & 25.67 & 26.03 & $25.85 \mathrm{ab}$ & 5025 & 55.00 & 52.63 \\
\hline & $\mathrm{K}_{2} \mathrm{SO}_{4} 0.5 \%$ & 26.24 & 27.65 & $26.95 \mathrm{ab}$ & 53.75 & 54.88 & 54.31 \\
\hline & $\mathrm{K}_{2} \mathrm{SO}_{4} 1 \%$ & 24.03 & 26.11 & $25.07 \mathrm{ab}$ & 57.50 & 58.50 & 58.00 \\
\hline \multirow{9}{*}{$\begin{array}{c}\text { After } \\
\text { Flowering }\end{array}$} & Mean & 25.40 & 26.63 & 26.01 & 51.13 & 57.08 & 54.10 \\
\hline & Control & 23.74 & 27.16 & $25.45 \mathrm{ab}$ & 49.00 & 52.25 & 50.63 \\
\hline & Urea $0.5 \%$ & 26.01 & 27.85 & $26.93 \mathrm{ab}$ & 52.00 & 56.19 & 54.09 \\
\hline & Urea $1 \%$ & 2607 & 28.11 & $27.09 \mathrm{a}$ & 53.00 & 56.00 & 54.50 \\
\hline & $\mathrm{ZnSO}_{4} 0.5 \%$ & 24.99 & 27.82 & $26.41 \mathrm{ab}$ & 47.50 & 59.63 & 53.56 \\
\hline & Urea $0.5 \%+\mathrm{ZnSO}_{4} 0.5 \%$ & 24.96 & 27.85 & $26.41 \mathrm{ab}$ & 53.00 & 54.13 & 53.56 \\
\hline & Urea $1 \%+\mathrm{ZnSO}_{4} 0.5 \%$ & 25.30 & 27.99 & $26.64 \mathrm{ab}$ & 56.00 & 59.25 & 57.63 \\
\hline & $\mathrm{K}_{2} \mathrm{SO}_{4} 0.5 \%$ & 25.23 & 26.73 & $25.98 \mathrm{ab}$ & 56.25 & 58.00 & 57.13 \\
\hline & $\mathrm{K}_{2} \mathrm{SO}_{4} 1 \%$ & 24.22 & 29.60 & $26.91 \mathrm{ab}$ & 49.25 & 56.88 & 53.06 \\
\hline \multirow{3}{*}{\multicolumn{2}{|c|}{$\mathrm{CV}(\%)$}} & 25.07 & 27.89 & 26.48 & 52.00 & 56.54 & 54.27 \\
\hline & & 25.23 & 27.26 & & $51.56 \mathrm{~b}$ & 56.81 a & \\
\hline & & \multicolumn{2}{|c|}{4.67} & \multicolumn{4}{|c|}{8.96} \\
\hline \multicolumn{8}{|c|}{$I^{\text {nd }}$ Experiment } \\
\hline \multirow{5}{*}{$\begin{array}{c}\text { Before } \\
\text { Flowering }\end{array}$} & Control & 25.16 & 28.50 & 26.83 & 41.75 & 52.75 & 47.25 \\
\hline & Urea $0.5 \%+\mathrm{K}_{2} \mathrm{SO}_{4} 0.5 \%$ & 23.22 & 30.09 & 26.66 & 49.75 & 62.88 & 56.31 \\
\hline & Urea $0.5 \%+\mathrm{K}_{2} \mathrm{SO}_{4} 1 \%$ & 26.14 & 27.92 & 27.03 & 46.50 & 55.38 & 50.94 \\
\hline & Urea $1 \%+\mathrm{K}_{2} \mathrm{SO}_{4} 0.5 \%$ & 26.80 & 31.08 & 28.94 & 54.25 & 65.00 & 59.63 \\
\hline & Urea $1 \%+\mathrm{K}_{2} \mathrm{SO}_{4} 1 \%$ & 27.13 & 26.15 & 26.64 & 51.25 & 59.88 & 55.56 \\
\hline \multirow{6}{*}{$\begin{array}{c}\text { After } \\
\text { Flowering }\end{array}$} & Mean & 25.69 & 28.75 & 27.22 & 48.70 & 59.18 & 53.94 \\
\hline & Control & 27.28 & 29.97 & 28.62 & 44.00 & 55.38 & 49.69 \\
\hline & Urea $0.5 \%+\mathrm{K}_{2} \mathrm{SO}_{4} 0.5 \%$ & 27.19 & 28.88 & 28.03 & 53.50 & 59.88 & 56.69 \\
\hline & Urea $0.5 \%+\mathrm{K}_{2} \mathrm{SO}_{4} 1 \%$ & 27.07 & 29.64 & 28.36 & 52.50 & 63.75 & 58.13 \\
\hline & Urea $1 \%+\mathrm{K}_{2} \mathrm{SO}_{4} 0.5 \%$ & 28.73 & 29.32 & 29.02 & 56.50 & 62.25 & 59.38 \\
\hline & Urea $1 \%+\mathrm{K}_{2} \mathrm{SO}_{4} 1 \%$ & 29.11 & 28.96 & 29.03 & 52.00 & 64.00 & 58.00 \\
\hline \multirow{3}{*}{\multicolumn{2}{|c|}{$\mathrm{CV}(\%)$}} & 27.88 & 29.35 & 28.61 & 51.70 & 61.05 & 56.38 \\
\hline & & 26.78 & 29.05 & & 50.20 b & 60.11 a & \\
\hline & & \multicolumn{2}{|c|}{$\mathbf{7 . 4 5}$} & \multicolumn{4}{|c|}{9.39} \\
\hline
\end{tabular}




\section{Effects of treatments on grain nitrogen $(N)$, potassium $(K)$, sulphur $(S)$, zinc $(\mathrm{Zn})$ and iron (Fe) concentrations}

With regard to effects of different foliar fertilizer treatments applied before and after flowering on grain N, K, S, Zn and Fe concentrations, it was observed that years created significant differences (Table 3). Because of greater precipitations of the second year (Table 2), nutrients concentrated in the grains and greater values were observed in the second year (Table 7 and 8).

Treatment periods did not have significant effects on grain $\mathrm{N}, \mathrm{K}, \mathrm{S}, \mathrm{Zn}$ and $\mathrm{Fe}$ concentrations in both experiments (Table 3). Treatment periods did not have significant effects on grain $\mathrm{K}$ concentrations in both experiments (Table 3). In the first $\begin{array}{llllll}\text { experiment, the greatest grain } \mathrm{K} \text { concentration was obtained from } 0.5 \% & \mathrm{~K}_{2} \mathrm{SO}_{4}\end{array}$ treatment. In the second experiment, treatments did not have significant effects on grain K concentrations (Table 9).

With regard to effects of general averages of treatments on $\mathrm{N}$ concentrations, it was observed that all treatments increased $\mathrm{N}$ concentrations as compared to the control treatment (Table 9). In the first experiment, the greatest $\mathrm{N}$ concentration $(2.26 \%)$ was observed in $0.5 \%$ urea treatment and the lowest $\mathrm{N}$ concentration $(2.12 \%)$ was observed in control treatments (Table 9). In the second experiment, the greatest $\mathrm{N}$ concentration was obtained from $1 \%$ Urea $+0.5 \% \mathrm{~K}_{2} \mathrm{SO}_{4}$ treatments (Table 9). Especially in the second experiment, AF treatments were more effective on mean $\mathrm{N}$ (Table 7) and protein concentrations (Table 4) than BF treatments. Thusly, $\mathrm{N}$ treatments close to flowering were reported to influence $\mathrm{N}$ uptake and protein contents (Banziger et al., 1994).

The critical extractable $\mathrm{S}$ level is commonly reported as $10 \mathrm{mg} \mathrm{S} \mathrm{kg}{ }^{-1}$, but is known to vary from 8 to $25 \mathrm{mg} \mathrm{kg}^{-1}$ (Mukhopadhyay and Mukhopadhyay, 1995) and 8 to $12 \mathrm{mg} \mathrm{kg}^{-1}$ as reported by Tandon (1991) depending on soil, crop, extractant and laboratory procedures. For wheat, the critical level for soil available $\mathrm{S}$ concentration was reported as $12 \mathrm{mg} \mathrm{kg}^{-1}$ (Rodríguez et al., 2001; Alfaro et al., 2006). According to the survey study results in Ankara, Turkey, more than $50 \%$ of the soil, plant straw and grain samples contained lower $S$ than the critical limits (Inal et al., 2003). As the average of the first and the second year, there was $10.7 \mathrm{mg} / \mathrm{kg}$ available $\mathrm{S}$ in soil (Table 1). This value did not result in $\mathrm{S}$ deficiency. In both experiments, treatment periods, treatments and interactions did not have significant effects on $\mathrm{S}$ concentrations (Table 3). Grain S concentrations lower than $1.2 \mathrm{mg} \mathrm{g}^{-1}$ and grain $\mathrm{N}: \mathrm{S}$ ratios higher than 17:1 appear to be critical values for S deficiency (Randall et al., 1981). In present study, $\mathrm{S}$ concentrations of both experiments were greater than $1.2 \mathrm{mg} \mathrm{g}^{-1}$ and $\mathrm{N}: \mathrm{S}$ ratios were lower than 17:1. Sulphur plays a significant role in methionine $(21 \% \mathrm{~S})$ and cysteine ( $27 \%$ S) formation, chlorophyll and protein synthesis, seed oil contents and nutritive quality accumulation (Tandon, 1986; Jamal et al., 2005). Sulphur status of wheat grain also influences quality parameters (Marschner, 1997; Zhao et al., 1999a; McGrath, 2003; Honermeier and Simioniuc, 2004). Grain N:S ratio influences bread-making quality and rheological characteristics of the dough.

In recent studies, a new strategy called as "agronomic biofortification" have come into prominence. In this strategy, selection, breeding and molecular methods are employed and improvement of grain micro nutrient contents and bio-availabilities are targeted. Such a strategy gained a great support because of sustainability and widespread impacts (Ortiz- Monasterio et al., 2007; Cakmak, 2008). 
Table 7. Effects of different foliar fertilizer treatments and combinations, applied before and after flowering, on grain $K, N, S$ concentrations and $N / S$ ratio of Altınbaşak bread wheat cultivar

\begin{tabular}{|c|c|c|c|c|c|c|c|c|c|c|c|}
\hline \multirow{2}{*}{$\begin{array}{l}\text { Appl. } \\
\text { Time }\end{array}$} & \multirow{2}{*}{ Applications } & \multicolumn{3}{|c|}{$\mathrm{K}(\%)$} & \multicolumn{3}{|c|}{$\mathbf{N}(\%)$} & \multicolumn{3}{|c|}{$\mathrm{S}(\%)$} & \multirow{2}{*}{$\frac{\text { N/S }}{\text { Mean" }}$} \\
\hline & & $1^{\text {st }}$ Year & $2^{\text {nd }}$ Year & Mean & $1^{\text {st }}$ Year & $2^{\text {nd }}$ Year & Mean & $\mathbf{1}^{\text {st }}$ Year & $2^{\text {nd }}$ Year & Mean & \\
\hline \multicolumn{12}{|c|}{$I^{\text {st }}$ Experiment } \\
\hline \multirow{8}{*}{$\begin{array}{l}\text { Before } \\
\text { Flowering }\end{array}$} & Control & 0.339 & 0.365 & 0.352 & $2.101 \mathrm{jk}$ & $2.12 \mathrm{~h}-\mathrm{k}$ & 2.11 & 0.139 & 0.156 & 0.148 & 0.139 \\
\hline & Urea $0.5 \%$ & 0.346 & 0.375 & 0.361 & $2.17 \mathrm{~d}-\mathrm{k}$ & $2.36 \mathrm{a}$ & 2.26 & 0.131 & 0.152 & 0.142 & 0.131 \\
\hline & Urea $1 \%$ & 0.332 & 0.360 & 0.346 & $2.15 \mathrm{f}-\mathrm{k}$ & $2.22 b-1$ & 2.18 & 0.140 & 0.154 & 0.147 & 0.140 \\
\hline & $\mathrm{ZnSO}_{4} 0.5 \%$ & 0.327 & 0.355 & 0.341 & $2.08 \mathrm{jk}$ & $2.25 \mathrm{a}-\mathrm{h}$ & 2.17 & 0.123 & 0.153 & 0.138 & 0.123 \\
\hline & $\begin{array}{l}\text { Urea } 0.5 \%+ \\
\mathrm{ZnSO}_{4} 0.5 \%\end{array}$ & 0.333 & 0.355 & 0.344 & $2.15 \mathrm{e}-\mathrm{k}$ & $2.30 \mathrm{abc}$ & 2.23 & 0.138 & 0.157 & 0.148 & 0.138 \\
\hline & $\begin{array}{c}\text { Urea } 1 \% \\
+\mathrm{ZnSO}_{4} 0.5 \\
\%\end{array}$ & 0.338 & 0.363 & 0.351 & $2.09 \mathrm{jk}$ & $2.32 \mathrm{abc}$ & 2.20 & 0.131 & 0.162 & 0.146 & 0.131 \\
\hline & $\mathrm{K}_{2} \mathrm{SO}_{4} 0.5 \%$ & 0.348 & 0.373 & 0.361 & $2.15 \mathrm{f}-\mathrm{k}$ & $2.28 \mathrm{a}-\mathrm{e}$ & 2.21 & 0.132 & 0.154 & 0.143 & 0.132 \\
\hline & $\mathrm{K}_{2} \mathrm{SO}_{4} 1 \%$ & 0.341 & 0.363 & 0.352 & $2.11 \mathrm{jjk}$ & $2.22 \mathrm{~b}-1$ & 2.16 & 0.142 & 0.154 & 0.148 & 0.142 \\
\hline & Mean & 0.338 & 0.363 & 0.351 & 2.12 & 2.26 & 2.19 & 0.135 & 0.155 & 0.145 & 15.2 \\
\hline \multirow{11}{*}{$\begin{array}{c}\text { After } \\
\text { Flowering }\end{array}$} & Control & 0.338 & 0.363 & 0.351 & $2.07 \mathrm{k}$ & $2.21 \mathrm{c}-\mathrm{j}$ & 2.14 & 0.141 & 0.161 & 0.151 & 14.2 \\
\hline & Urea $0.5 \%$ & 0.338 & 0.365 & 0.352 & $2.21 \mathrm{c}-\mathrm{j}$ & $2.30 \mathrm{a}-\mathrm{d}$ & 2.25 & 0.146 & 0.157 & 0.152 & 15.0 \\
\hline & Urea $1 \%$ & 0.328 & 0.358 & 0.343 & $2.15 \mathrm{f}-\mathrm{k}$ & $2.27 \mathrm{a}-\mathrm{f}$ & 2.21 & 0.134 & 0.154 & 0.144 & 15.4 \\
\hline & $\mathrm{ZnSO}_{4} 0.5 \%$ & 0.332 & 0.360 & 0.346 & $2.15 \mathrm{f}-\mathrm{k}$ & $2.26 \mathrm{a}-\mathrm{g}$ & 2.20 & 0.133 & 0.155 & 0.144 & 15.3 \\
\hline & $\begin{array}{l}\text { Urea } 0.5 \%+ \\
\mathrm{ZnSO}_{4} 0.5 \%\end{array}$ & 0.331 & 0.355 & 0.343 & 2.12 1jk & 2.28 a-e & 2.20 & 0.138 & 0.168 & 0.153 & 14.5 \\
\hline & $\begin{array}{c}\text { Urea } 1 \%+ \\
\mathrm{ZnSO}_{4} 0.5 \%\end{array}$ & 0.332 & 0.353 & 0.343 & $2.14 \mathrm{~g}-\mathrm{k}$ & $2.26 \mathrm{a}-\mathrm{g}$ & 2.20 & 0.131 & 0.160 & 0.146 & 15.2 \\
\hline & $\mathrm{K}_{2} \mathrm{SO}_{4} 0.5 \%$ & 0.353 & 0.380 & 0.367 & $2.20 \mathrm{c}-\mathrm{k}$ & $2.20 \mathrm{c}-\mathrm{k}$ & 2.20 & 0.149 & 0.164 & 0.156 & 14.1 \\
\hline & $\mathrm{K}_{2} \mathrm{SO}_{4} 1 \%$ & 0.332 & 0.355 & 0.344 & $2.111 \mathrm{jk}$ & $2.35 \mathrm{ab}$ & 2.23 & 0.138 & 0.163 & 0.150 & 14.9 \\
\hline & Mean & 0.336 & 0.361 & 0.349 & 2.14 & 2.27 & 2.20 & 0.139 & 0.160 & 0.150 & 14.8 \\
\hline & $\begin{array}{c}\text { General } \\
\text { mean }\end{array}$ & $0.337 b$ & $0.362 \mathrm{a}$ & & $2.13 \mathrm{~b}$ & $2.26 \mathrm{a}$ & & 0.137 b & 0.158 a & & \\
\hline & \multicolumn{2}{|l|}{ CV (\%) } & 4.62 & & & 2.16 & & & 5.77 & & \\
\hline \multicolumn{12}{|c|}{$I^{n d}$ Experiment } \\
\hline \multirow{5}{*}{$\begin{array}{c}\text { Before } \\
\text { Flowering }\end{array}$} & Control & 0.357 & 0.388 & 0.373 & 2.09 & 2.28 & 2.18 & 0.147 & 0.171 & 0.156 & 13.8 \\
\hline & $\begin{array}{c}\text { Urea } 0.5 \% \\
+\mathrm{K}_{2} \mathrm{SO}_{4} 0.5 \\
\%\end{array}$ & 0.341 & 0.368 & 0.355 & 2.06 & 2.42 & 2.24 & 0.134 & 0.161 & 0.149 & 15.2 \\
\hline & $\begin{array}{c}\text { Urea } 0.5 \% \\
+\mathrm{K}_{2} \mathrm{SO}_{4} 1 \%\end{array}$ & 0.360 & 0.398 & 0.379 & 2.09 & 2.29 & 2.19 & 0.142 & 0.169 & 0.152 & 14.2 \\
\hline & $\begin{array}{c}\text { Urea } 1 \%+ \\
\mathrm{K}_{2} \mathrm{SO}_{4} 0.5 \%\end{array}$ & 0.351 & 0.383 & 0.367 & 2.19 & 2.44 & 2.31 & 0.138 & 0.166 & 0.155 & 15.3 \\
\hline & $\begin{array}{l}\text { Urea } 1 \%+ \\
\mathrm{K}_{2} \mathrm{SO}_{4} 1 \%\end{array}$ & 0.345 & 0.373 & 0.359 & 2.05 & 2.36 & 2.20 & 0.139 & 0.163 & 0.149 & 14.6 \\
\hline \multicolumn{2}{|r|}{ Mean } & 0.351 & 0.382 & 0.367 & $2.09 \mathrm{~b}$ & $2.36 \mathrm{a}$ & 2.23 & 0.140 & 0.164 & 0.152 & 14.6 \\
\hline \multirow{8}{*}{$\begin{array}{c}\text { After } \\
\text { Flowering }\end{array}$} & Control & 0.354 & 0.385 & 0.370 & 2.30 & 2.29 & 2.30 & 0.149 & 0.165 & 0.16 & 14.7 \\
\hline & $\begin{array}{l}\text { Urea } 0.5 \%+ \\
\mathrm{K}_{2} \mathrm{SO}_{4} 0.5 \%\end{array}$ & 0.359 & 0.390 & 0.375 & 2.11 & 2.33 & 2.22 & 0.148 & 0.164 & 0.154 & 14.3 \\
\hline & $\begin{array}{c}\text { Urea } 0.5 \%+ \\
\mathrm{K}_{2} \mathrm{SO}_{4} 1 \%\end{array}$ & 0.355 & 0.385 & 0.370 & 2.28 & 2.37 & 2.33 & 0.144 & 0.162 & 0.156 & 15.2 \\
\hline & $\mid \begin{array}{c}\text { Urea } 1 \%+ \\
\mathrm{K}_{2} \mathrm{SO}_{4} 0.5 \%\end{array}$ & 0.354 & 0.383 & 0.369 & 2.46 & 2.40 & 2.43 & 0.149 & 0.173 & 0.157 & 15.2 \\
\hline & $\begin{array}{l}\text { Urea } 1 \%+ \\
\mathrm{K}_{2} \mathrm{SO}_{4} 1 \%\end{array}$ & 0.348 & 0.373 & 0.361 & 2.16 & 2.32 & 2.24 & 0.143 & 0.158 & 0.153 & 14.9 \\
\hline & Mean & 0.354 & 0.383 & 0.369 & $2.26 \mathrm{ab}$ & $2.34 \mathrm{a}$ & 2.30 & 0.146 & 0.166 & 0.156 & 14.8 \\
\hline & $\begin{array}{c}\text { General } \\
\text { mean }\end{array}$ & 0.352 & 0.382 & & $2.18 \mathrm{~b}$ & $2.35 \mathrm{a}$ & & 0.143 b & 0.165 a & & \\
\hline & \multicolumn{2}{|l|}{ CV (\%) } & 4.88 & & & 4.16 & & & 6.23 & & \\
\hline
\end{tabular}




$$
-4336 \text { - }
$$

Table 8. Effects of different foliar fertilizer treatments and combinations, applied before and after flowering, on grain Zn and Fe concentrations of Altınbaşak bread wheat cultivar

\begin{tabular}{|c|c|c|c|c|c|c|c|}
\hline \multirow{2}{*}{ Appl. Time } & \multirow{2}{*}{ Applications } & \multicolumn{3}{|c|}{$\mathrm{Zn}\left(\mathrm{mg} \mathrm{kg}^{-1}\right)$} & \multicolumn{3}{|c|}{$\mathrm{Fe}\left(\mathrm{mg} \mathrm{kg}^{-1}\right)$} \\
\hline & & $1^{\text {st }}$ Year & $2^{\text {nd }}$ Year & Mean & $1^{\text {st }}$ Year & $2^{\text {nd }}$ Year & Mean \\
\hline \multicolumn{8}{|c|}{$I^{\text {st }}$ Experiment } \\
\hline \multirow{8}{*}{$\begin{array}{c}\text { Before } \\
\text { Flowering }\end{array}$} & Control & $19.3 \mathrm{e}$ & $23.6 \mathrm{e}$ & 21.5 & 22.6 & 33.8 & 28.3 \\
\hline & Urea $0.5 \%$ & $21.6 \mathrm{e}$ & $23.0 \mathrm{e}$ & 22.2 & 27.2 & 33.0 & 30.0 \\
\hline & Urea $1 \%$ & $21.8 \mathrm{e}$ & $22.2 \mathrm{e}$ & 22.0 & 30.5 & 30.8 & 30.6 \\
\hline & $\mathrm{ZnSO}_{4} 0.5 \%$ & $33.9 \mathrm{~cd}$ & $41.4 \mathrm{abc}$ & 37.7 & 27.1 & 37.4 & 32.3 \\
\hline & $\begin{array}{l}\text { Urea } 0.5 \%+ \\
\mathrm{ZnSO}_{4} 0.5 \%\end{array}$ & $38.0 \mathrm{abc}$ & $42.3 \mathrm{abc}$ & 40.2 & 32.2 & 38.3 & 35.2 \\
\hline & $\begin{array}{c}\text { Urea } 1 \%+ \\
\mathrm{ZnSO}_{4} 0.5 \%\end{array}$ & $35.2 \mathrm{c}$ & $45.0 \mathrm{a}$ & 40.1 & 29.6 & 40.2 & 35.1 \\
\hline & $\mathrm{K}_{2} \mathrm{SO}_{4} 0.5 \%$ & $18.7 \mathrm{e}$ & $22.7 \mathrm{e}$ & 20.7 & 27.1 & 33.2 & 30.2 \\
\hline & $\mathrm{K}_{2} \mathrm{SO}_{4} 1 \%$ & $22.9 \mathrm{e}$ & $23.2 \mathrm{e}$ & 23.0 & 24.6 & 30.1 & 27.4 \\
\hline \multirow{9}{*}{$\begin{array}{c}\text { After } \\
\text { Flowering }\end{array}$} & Mean & 26.4 & 30.4 & 28.4 & 27.6 & 34.7 & 31.1 \\
\hline & Control & $19.2 \mathrm{e}$ & $24.3 \mathrm{e}$ & 21.9 & 26.3 & 34.5 & 30.5 \\
\hline & Urea $0.5 \%$ & $17.5 \mathrm{e}$ & $23.2 \mathrm{e}$ & 20.4 & 27.1 & 31.2 & 29.2 \\
\hline & Urea $1 \%$ & $19.7 \mathrm{e}$ & $22.8 \mathrm{e}$ & 21.4 & 27.0 & 28.4 & 27.8 \\
\hline & $\mathrm{ZnSO}_{4} 0.5 \%$ & $40.7 \mathrm{abc}$ & $38.7 \mathrm{abc}$ & 39.8 & 29.1 & 35.0 & 32.1 \\
\hline & $\begin{array}{l}\text { Urea } 0.5 \%+ \\
\mathrm{ZnSO}_{4} 0.5 \%\end{array}$ & $35.5 \mathrm{bc}$ & $44.0 \mathrm{ab}$ & 39.8 & 27.4 & 36.4 & 32.0 \\
\hline & $\begin{array}{c}\text { Urea } 1 \%+ \\
\mathrm{ZnSO}_{4} 0.5 \%\end{array}$ & $37.4 \mathrm{abc}$ & $39.6 \mathrm{abc}$ & 38.5 & 27.6 & 37.3 & 32.4 \\
\hline & $\mathrm{K}_{2} \mathrm{SO}_{4} 0.5 \%$ & $17.1 \mathrm{e}$ & $25.5 \mathrm{de}$ & 21.3 & 28.2 & 37.6 & 33.0 \\
\hline & $\mathrm{K}_{2} \mathrm{SO}_{4} 1 \%$ & $18.0 \mathrm{e}$ & $23.1 \mathrm{e}$ & 20.6 & 23.2 & 32.2 & 28.1 \\
\hline \multirow{3}{*}{\multicolumn{2}{|c|}{\begin{tabular}{c|} 
Mean \\
General mean \\
$\mathrm{CV}(\%)$ \\
\end{tabular}}} & 25.7 & 30.2 & 27.9 & 27.0 & 34.2 & 30.6 \\
\hline & & $26.0 \mathrm{~b}$ & $30.3 \mathrm{a}$ & & $27.3 \mathrm{~b}$ & $34.4 \mathrm{a}$ & \\
\hline & & \multicolumn{3}{|c|}{10.97} & \multicolumn{3}{|c|}{15.08} \\
\hline \multicolumn{8}{|c|}{$I^{\text {nd }}$ Experiment } \\
\hline \multirow{5}{*}{$\begin{array}{c}\text { Before } \\
\text { Flowering }\end{array}$} & Control & 18.0 & 27.0 & 22.5 & 25.4 & 37.5 & 31.4 \\
\hline & $\begin{array}{l}\text { Urea } 0.5 \%+ \\
\mathrm{K}_{2} \mathrm{SO}_{4} 0.5 \%\end{array}$ & 19.3 & 28.3 & 23.8 & 21.6 & 35.3 & 28.4 \\
\hline & $\begin{array}{c}\text { Urea } 0.5 \%+ \\
\mathrm{K}_{2} \mathrm{SO}_{4} 1 \%\end{array}$ & 20.0 & 28.5 & 24.3 & 22.0 & 35.6 & 28.8 \\
\hline & $\begin{array}{c}\text { Urea } 1 \%+ \\
\mathrm{K}_{2} \mathrm{SO}_{4} 0.5 \%\end{array}$ & 19.4 & 27.5 & 23.5 & 24.3 & 40.9 & 32.6 \\
\hline & $\begin{array}{l}\text { Urea } 1 \%+ \\
\mathrm{K}_{2} \mathrm{SO}_{4} 1 \% \\
\end{array}$ & 18.1 & 27.6 & 22.8 & 21.5 & 33.8 & 27.7 \\
\hline \multirow{6}{*}{$\begin{array}{c}\text { After } \\
\text { Flowering }\end{array}$} & Mean & 19.0 & 27.8 & 23.4 & 22.9 & 36.6 & 29.8 \\
\hline & Control & 18.2 & 25.8 & 22.0 & 23.4 & 38.6 & 31.0 \\
\hline & $\begin{array}{l}\text { Urea } 0.5 \%+ \\
\mathrm{K}_{2} \mathrm{SO}_{4} 0.5 \%\end{array}$ & 18.3 & 31.7 & 25.0 & 23.3 & 38.3 & 30.8 \\
\hline & $\begin{array}{c}\text { Urea } 0.5 \%+ \\
\mathrm{K}_{2} \mathrm{SO}_{4} 1 \%\end{array}$ & 17.9 & 26.8 & 22.3 & 32.3 & 36.0 & 34.2 \\
\hline & $\begin{array}{c}\text { Urea } 1 \%+ \\
\mathrm{K}_{2} \mathrm{SO}_{4} 0.5 \%\end{array}$ & 19.1 & 27.5 & 23.3 & 24.9 & 37.8 & 31.3 \\
\hline & $\begin{array}{l}\text { Urea } 1 \%+ \\
\mathrm{K}_{2} \mathrm{SO}_{4} 1 \%\end{array}$ & 18.4 & 26.1 & 22.2 & 28.6 & 34.5 & 31.6 \\
\hline & Mean & 18.4 & 27.6 & 23.0 & 26.5 & 37.0 & 31.8 \\
\hline \multirow{2}{*}{\multicolumn{2}{|c|}{$\begin{array}{c}\text { General mean } \\
\mathrm{CV}(\%) \\
\end{array}$}} & $18.7 \mathrm{~b}$ & 27.7 a & & 24.7 b & 36.8 a & \\
\hline & & \multicolumn{3}{|c|}{8.98} & \multicolumn{3}{|c|}{12.72} \\
\hline
\end{tabular}

Considering the effects of different foliar fertilizer treatments before and after flowering periods on grain $\mathrm{Zn}$ and $\mathrm{Fe}$ concentrations, it was observed that both the years and the treatments were found to be significant (Table 3). Treatment periods (BF and AF) were not found to be significant (Table 3). In Table $8,0.5 \% \mathrm{ZnSO}_{4} .7 \mathrm{H}_{2} \mathrm{O}$, 
$1 \%$ Urea+0.5\% $\mathrm{ZnSO}_{4} .7 \mathrm{H}_{2} \mathrm{O}$ and $0.5 \%$ Urea+0.5\% $\mathrm{ZnSO}_{4} .7 \mathrm{H}_{2} \mathrm{O}$ treatments resulted in significant increases in grain $\mathrm{Zn}$ concentrations as compared to the other treatments for both years and BF-AF periods. Similarly, higher grain Zn concentration results were obtained from the general averages of treatments (Table 9). Zinc sulphate heptahydrate and urea combination was more effective on grain $\mathrm{Zn}$ concentrations as compared to single $\mathrm{ZnSO}_{4} .7 \mathrm{H}_{2} \mathrm{O}$ treatment (Table 8 and 9 ).

Table 9. Effects of different foliar fertilizer treatments and combinations on general mean of grain $N, K S, Z n$ and Fe concentrations of Altınbaşak bread wheat cultivar

\begin{tabular}{|c|c|c|c|c|c|c|}
\hline & \multirow{3}{*}{ Applications } & \multicolumn{5}{|c|}{ General Mean } \\
\hline & & $\mathbf{K}$ & $\mathbf{N}$ & $\mathbf{S}$ & $\mathbf{Z n}$ & $\mathbf{F e}$ \\
\hline & & \multicolumn{3}{|c|}{$(\%)$} & \multicolumn{2}{|c|}{$\left(\mathrm{mg} \mathrm{kg}^{-1}\right)$} \\
\hline \multirow{8}{*}{$\begin{array}{c}\text { Ist }^{\text {Experiment }} \\
\text { Expen }\end{array}$} & Control & $0.352 \mathrm{ab}$ & $2.12 \mathrm{c}$ & 0.149 & $21.7 \mathrm{~b}$ & $29.4 \mathrm{ab}$ \\
\hline & Urea $0.5 \%$ & $0.357 \mathrm{ab}$ & $2.26 \mathrm{a}$ & 0.147 & $21.3 \mathrm{~b}$ & $29.5 \mathrm{ab}$ \\
\hline & Urea $1 \%$ & $0.345 \mathrm{~b}$ & $2.20 \mathrm{~b}$ & 0.146 & $21.7 \mathrm{~b}$ & $29.2 \mathrm{ab}$ \\
\hline & $\mathrm{ZnSO} 40.5 \%$ & $0.344 \mathrm{~b}$ & $2.18 \mathrm{~b}$ & 0.141 & $38.7 \mathrm{a}$ & $32.2 \mathrm{ab}$ \\
\hline & Urea $0.5 \%+\mathrm{ZnSO}_{4} 0.5 \%$ & $0.344 \mathrm{~b}$ & $2.21 \mathrm{ab}$ & 0.150 & $39.9 \mathrm{a}$ & $33.6 \mathrm{a}$ \\
\hline & Urea $1 \%+\mathrm{ZnSO}_{4} 0.5 \%$ & $0.347 \mathrm{ab}$ & $2.20 \mathrm{~b}$ & 0.146 & $39.3 \mathrm{a}$ & $33.7 \mathrm{a}$ \\
\hline & $\mathrm{K}_{2} \mathrm{SO}_{4} 0.5 \%$ & $0.364 \mathrm{a}$ & $2.21 \mathrm{~b}$ & 0.149 & $21.0 \mathrm{~b}$ & $31.6 \mathrm{ab}$ \\
\hline & $\mathrm{K}_{2} \mathrm{SO}_{4} 1 \%$ & $0.348 \mathrm{ab}$ & $2.20 \mathrm{~b}$ & 0.149 & $21.8 \mathrm{~b}$ & $27.7 \mathrm{~b}$ \\
\hline \multirow{5}{*}{$\begin{array}{c}\text { II }^{\text {nd }} \\
\text { Experiment }\end{array}$} & Control & 0.371 & $2.24 \mathrm{~b}$ & 0.158 & $22.2 \mathrm{~b}$ & 31.2 \\
\hline & Urea $0.5 \%+\mathrm{K}_{2} \mathrm{SO}_{4} 0.5 \%$ & 0.365 & $2.23 \mathrm{~b}$ & 0.151 & $24.4 \mathrm{a}$ & 29.6 \\
\hline & Urea $0.5 \%+\mathrm{K}_{2} \mathrm{SO}_{4} 1 \%$ & 0.375 & $2.26 \mathrm{~b}$ & 0.154 & $23.3 \mathrm{ab}$ & 31.5 \\
\hline & Urea $1 \%+\mathrm{K}_{2} \mathrm{SO}_{4} 0.5 \%$ & 0.368 & $2.37 \mathrm{a}$ & 0.156 & $23.3 \mathrm{ab}$ & 31.9 \\
\hline & Urea $1 \%+\mathrm{K}_{2} \mathrm{SO}_{4} 1 \%$ & 0.360 & $2.22 \mathrm{~b}$ & 0.151 & $22.5 \mathrm{ab}$ & 29.1 \\
\hline
\end{tabular}

It was stated in previous studies that when the sufficient $\mathrm{Zn}$ levels were supplied to the growth ambient for plants, both soil and foliar $\mathrm{N}$ treatments increased grain $\mathrm{Zn}$ concentrations (Kutman, 2010; Kutman et al., 2010; Cakmak et al., 2010). Y1lmaz et al. (1997) indicated that soil, foliar, seed and combined $\mathrm{Zn}$ treatments yielded significant increases in plant and grain $\mathrm{Zn}$ concentrations. It was also reported that foliar zinc treatments improved $\mathrm{Zn}$ concentrations of the grains and especially of the endosperm (Jiang et al., 2007; Cakmak et al., 2010; Xue et al., 2012; Zhang et al., 2012).

As compared to control treatments in the second experiment, combined urea and $\mathrm{K}_{2} \mathrm{SO}_{4}$ treatments yielded significant increases in grain $\mathrm{Zn}$ concentrations (Table 9). Especially, the effects of $0.5 \%$ Urea $+0.5 \% \mathrm{~K}_{2} \mathrm{SO}_{4}$ treatments were more remarkable. Such a value was still behind the effects of urea+ $\mathrm{ZnSO}_{4} .7 \mathrm{H}_{2} \mathrm{O}$ treatments of the first experiment on $\mathrm{Zn}$ concentrations.

Orman and Ok (2012) reported that $\mathrm{S}$ treatments did not have significant effects on grain $\mathrm{Zn}$ concentrations under sufficient $\mathrm{Zn}$ conditions, but increased grain $\mathrm{Zn}$ concentrations under insufficient $\mathrm{Zn}$ conditions. In the same study, S treatments did not have significant effects on grain Fe concentrations under both sufficient and insufficient $\mathrm{Zn}$ conditions. Considering the general averages of the treatments of the first experiment, the greatest $\mathrm{Fe}$ concentration was obtained from combined urea and $\mathrm{ZnSO}_{4} .7 \mathrm{H}_{2} \mathrm{O}$ treatments and the lowest $\mathrm{Fe}$ concentration was obtained from $1 \% \mathrm{~K}_{2} \mathrm{SO}_{4}$ treatment (Table 9). Similar findings were also reported by the other researchers (Cakmak et al., 2010; Kutman, 2010; Kutman et al., 2010; Shi et al., 2010). In a study conducted by Kutman (2010), increasing $\mathrm{N}$ treatments increased $\mathrm{Zn}$ and $\mathrm{Fe}$ concentrations by up to $100 \%$. Such an impact of $\mathrm{N}$ on $\mathrm{Zn}$ concentrations disappeared 
under insufficient $\mathrm{Zn}$ conditions; on the other hand, combined high $\mathrm{N}$ and $\mathrm{Zn}$ treatments resulted in synergic effect. Significant correlations were reported between the $N$ transported to the grain by remobilization and $\mathrm{Zn}$ and Fe supplied to the grain by remobilization (Kutman et al., 2011). There are also some genetic findings about the close relationships between the nitrogen transported from aged leaf tissues into the grain and grain $\mathrm{Zn}$ and Fe concentrations (Uauy et al., 2006; Distelfeld et al., 2007; Waters et al., 2009).

\section{Conclusion}

It was concluded based on present findings that foliar fertilizer treatments generally had positive impacts on quality of wheat grains. In this sense, it was observed in both experiments that all treatments increased yield and sedimentation values as compared to the control treatments. In the first experiment, $0.5 \%$ urea treatment was prominent for yield, nitrogen and protein and urea $+\mathrm{ZnSO}_{4} .7 \mathrm{H}_{2} \mathrm{O}$ treatments for grain zinc and iron concentrations. In the second experiment, $1 \%$ urea+0.5\% $\quad \mathrm{K}_{2} \mathrm{SO}_{4}$ treatments were prominent for protein and grain nitrogen and $1 \%$ urea $+1 \% \mathrm{~K}_{2} \mathrm{SO}_{4}$ and $0.5 \%$ urea $+0.5 \%$ $\mathrm{K}_{2} \mathrm{SO}_{4}$ treatments for yield. Further research is recommended to be conducted with greater number of wheat genotypes about the effects of combined urea, $\mathrm{K}_{2} \mathrm{SO}_{4}$ and $\mathrm{ZnSO}_{4} .7 \mathrm{H}_{2} \mathrm{O}$ treatments on wheat yield, quality and grain $\mathrm{Zn}$ and Fe levels.

Conflict of interests. The author has not declared any conflict of interests.

Acknowledgements. This research work was financially supported by Republic of Turkey, Ministry of Food, Agriculture and Livestock (Project Code No: TAGEM/TSKAD/15/A13/P04/05).

\section{REFERENCES}

[1] Alfaro, M., Bernier, R., Iraira, S. (2006): Efecto de Fuentes de Azufre Sobre Rendimiento y Calidad de Trigo y pradera en dos Andisoles. - Agricultura Técnica (Chile) 66: 283294.

[2] Allison, L. E., Moodie, C. D. (1965): Carbonate. - In: Black, C. A. (ed.) Methods of Soil Analysis, Part 2. Agronomy 9: 1379-1400. Am. Soc. of Agron., Inc., Madison, Wisconsin, U.S.A.

[3] Arkley, T. H. (1961): Sulphur Compound of Soil Systems. - Ph. D. Thesis. p.1-126. University of California, Berkley, USA.

[4] Banziger, M., Feil, B., Schmid, J. E., Stamp, P. (1994): Utilization Of Lateapplied Fertilizer Nitrogen By Spring Wheat Genotypes. - Eur. Journal of Agronomy 3: 63-69.

[5] Bouyoucous, G. D. (1951): A Eecablibration of the Hydrometer Method for Making Mechanic Analysis of the Soil. - Agronomy Journal 43: 434-438.

[6] Cakmak, I. (2008): Enrichment Of Cereal Grains With Zinc: Agronomic Or Genetic Biofortification? - Plant and Soil 302: 1-17.

[7] Cakmak, I., Kalaycı, M., Kaya, Y., Torun, A. A., Aydın, N., Wang, Y., Arisoy, Z., Erdem, H., Gökmen, O., Öztürk, L., Horst, W. J. (2010): Biofortification and Localization of Zinc in Wheat Grain. - Journal of Agriculture and Food Chemistry 58: 9092-9102.

[8] Cakmak, I., Kutman, U. B. (2018): Agronomic Biofortification of Cereals with Zinc: A Review. - Eurosian Journal of Soil Science 69: 172-180.

[9] Carson, P. L. (1980): Recommended Potassium Test. - In: Recommended Chemical Soil Test Procedures for the North Central Region. Rev. Ed. North Central. Regional 
Publicaton no. 221. p.20-21. North Dakota Agric. Exp. Stn. North Dakota State University, Fargo USA.

[10] Distelfeld, A., Cakmak, I., Peleg, Z., Ozturk, L., Yazici, A., Budak, H., Saranga, Y., Fahima, T. (2007): Multiple Qtl-Effects Of Wheat Gpc-B1 Locus On Grain Protein And Micronutrient Concentrations. - Physiologia Plantarum 129: 635-643.

[11] Erdal, I., Yilmaz, A., Taban, S., Eker, S., Cakmak, I. (2002): Phytic Acid And Phosphorus Concentrations İn Seeds Of Wheat Cultivars Grown With And Without Zinc Fertilization. - Journal of Plant Nutrition 25(1): 113-127.

[12] Erekul, O., Götz, K. P., Koca, Y. O. (2012): Effect of Sulphur and Nitrogen Fertilization on Bread-Making Quality of Wheat (Triticum aestivum L.) Varieties under Mediterranean Climate Conditions. - Journal of Applied Botany and Food Quality 85: 17-22.

[13] Finney, K. F., Meyer, J. W., Smith, F. W., Fryer, H. C. (1957): Effect of Foliar Spraying on Pawnee Wheat with Urea Solution on Yield, Protein Content, and Protein Quality. Agronomy Journal 49: 341-347.

[14] Granvogl, M., Wieser, H., Koehler, P., Von Tucher, S., Schieberle, P. (2007): Influence Of Sulfur Fertilization On The Amounts Of Free Amino Acids İn Wheat. Correlation With Baking Properties As Well As With 3-Aminopropionamide And Acrylamide Generation During Baking. - Journal of Agriculture and Food Chemistry 55: 4271-4277.

[15] Gupta, V. K., Sanjeev, K., Singh, A. K. (2004): Yield and Quality of Wheat (Triticum aestivum) as Influenced by Sulphur Nutrition and Weed Management. - Indian Journal of Agriculturel. Science 74(5): 254-256.

[16] Habib, M. (2009): Effect of Foliar Application of $\mathrm{Zn}$ and Fe on Wheat Yield and Quality. - African Journal Biotechnology 8(24): 6795-6798.

[17] Hamouda, H. A., EI-Dahshouri, M. F., Manal, F. M., Thalooth, A. T. (2015): Growth, Yield and Nutrient Status of Wheat Plants as Affected by Potassium and Iron Foliar Application in Sandy Soil. - International Journal of Chemtech Research 8: 1473-1481.

[18] Honermeier, B., Simioniuc, F. (2004): Qualitätsmanagement von Backweizen. - Getreide Mag. 9(4): 212-215.

[19] Inal, A., Güneş, A., Alpaslan, M., Adak, M. S., Taban, S., Eraslan, F. (2003): Diagnosis of Sulfur Deficiency and Effects of Sulfur on Yield and Yield Components of Wheat Grown in Central Anatolia, Turkey. - Journal of Plant Nutrition 26(7): 1483-1498.

[20] International Association for Cereal Chemistry. (1994): Standard Methods of the ICC. Verlag Moritz Schafer, Detmold, Germany.

[21] Jackson, M. L. (1959): Soil chemical analysis. - Englewood Cliffs, New Jersey.

[22] Jakhro, A. A., Jamro, G. H., Jamali, N. M., Jamali, L. A., Sheikh, S. A. (2000): Effect of Foliar Fertilization of Urea on the Quantitative and Qualitative Traits of Wheat (cv. Sarsabz). - Pak. J. Agri. Agril. Eng. Vet. Sci. 16(1-2): 5-9.

[23] Jamal, A., Fazli, I. S., Ahmad, S., Abdin, M. Z., Yun, S. J. (2005): Effect of Sulphur and Nitrogen Application on Growth Characteristics, Seed and Oil Yield of Soybean Cultivars. - Korean Journal of Crop Science 50(5): 340-345.

[24] Jiang, W., Struik, P. C., Lingna, J., van Keulen, H., Ming, Z., Stomph, T. J. (2007): Uptake and Distribution of Root-applied or Foliar-applied ${ }^{65} \mathrm{Zn}$ After Flowering in Aerobic Rice. - Annals of Applied Biology 150: 383-391.

[25] Khan, P., Memon, M. Y., Imtiaz, M., Aslam, M. (2009): Response of Wheat to Foliar and Soil Application of Urea at Different Growth Stages. - Pakistan Journal Botany 41(3): 1197-1204.

[26] Kutman, U. B. (2010): Roles Of Nitrogen And Zinc Nutrient İn Biofortification Of Wheat Grain. - Sabanci University. Phd Thesis.

[27] Kutman, U. B., Yildiz, B., Ozturk, L., Cakmak, I. (2010): Biofortification Of Durum Wheat With Zinc Through Soil And Foliar Applications Of Nitrogen. - Cereal Chemistry 87: $1-9$. 
[28] Kutman, U. B., Yildiz, B., Cakmak, I. (2011): Effect Of Nitrogen On Uptake, Remobilization And Partitioning Of Zinc And İron Throughout The Development Of Durum Wheat. - Plant and Soil 342: 149-164.

[29] Lindsay, W. L., Norvell, W. A. (1978): Development of a DTPA Soil Test for Zinc, Iron, Manganese and Copper. - Soil Science Society and America Journal 42: 421-428.

[30] Mailhot, W. C., Patton, J. C. (1988): Criteria of Flour Quality. - In: Pomeranz, Y. (ed.) Wheat: Chem. Technol. (vol. 11, pp. 69- 90) St. Paul: American association of Cereal Chemists.

[31] Marschner, H. (1995): Mineral Nutrition of Higher Plants. 2nd Edn. - Academic Press, London.

[32] Marschner, H. (1997): Sulfur supply, plant growth, and plant composition. - In: Mineral Nutrition of Higher Plants, Academic Press, Cambridge, 261-265.

[33] McDonald, G. K., Mousavvi Nik, M. (2009): Increasing the supply of sulphur increases the grain zinc concentration in bread and durum wheat. - UC Davis: The Proceedings of the International Plant Nutrition Colloquium XVI. Retrieved from: http://escholarship.org/uc/item/43k2r1h8.

[34] McGrath, S. P., Zhao, F. J. (1996): Sulphur Uptake, Yield Response and the Interactions between N and S in Winter Oilseed Rape (Brassica napus L.). - J. Agric. Sci. 126: 53-62.

[35] McGrath, S. P. (2003): Sulphur: A Secondary Nnutrient? Not anymore! - New AG International, March 2003: 70-76.

[36] Mukhopadhyay, A. K., Mukhopadhyay, P. (1995): An Overview of Sulphur Research in Soils of West Bengal, India. - Sulphur Agric. 19: 30-34.

[37] Olsen, S. R., Cole, C. V., Watanabe, F. S., Dean, L. A. (1954): Estimation of Available Phosphorus in Soil by Extraction with Sodium Bicarbonate. - USDA Circ., 939. U.S. Cov. Print Office, Washington D.C.

[38] Orman, Ş., Ok, H. (2012): Effects of Sulphur and Zinc Applications on Growth and Nutrition of Bread Wheat in Calcareous Clay Loam Soil. - African Journal of Biotechnology 11: 3080-3086.

[39] Ortiz-Monasterio, I., Palacios-Rojas, N., Meng, E., Pixley, K., Trethowan, R., Pena, R. J. (2007): Enhancing the Mineral and Vitamin Content of Wheat and Maize through Plant Breeding. - Journal of Cereal Science 46: 293-307.

[40] Ozkaya, H., Ozkaya, B. (2005): Tahıl ve Ürünleri Analiz Yöntemleri. - A.Ü. Mühendislik Fak. Gıda Müh. Bölümü Gıda Teknolojisi Yayınları N0:30, Ankara.

[41] Peltonen, J. (1992): Ear Developmental Stage Used for Timing Supplemental Nitrogen Application to Spring Wheat. - Crop Science 32: 1029-1033.

[42] Rahman, M. Z., Islam, M. R., Karim, M. A., Islam, M. T. (2014): Response of Wheat to Foliar Application of Urea Fertilizer. - Journal of Sylhet Agricultural University 1(1): 3943.

[43] Randall, P. J., Spencer, K., Freney, J. R. (1981): Sulphur and Nitrojen Fertiliser Effect on Wheat. I. Concentrations of Sulphur and the Nitrojen to Sulphur Ratio in Grain, in relation to the yield response. - Australian Journal of Agricultural Research 32: 203-212.

[44] Randall, P. J., Wrigley, C. W. (1986): Effects of Sulfur Supply on the Yield, Composition and Quality of Grain from Cereals, Oilseeds, and Legumes. - Advances in Cereal Science and Technology 8: 171-206.

[45] Rodríguez, J., Pinochet, D., Matus, F. (2001): Fertilización de los cultivos. - LOM Ediciones. Santiago, Chile. 117 pp.

[46] Ryant, P., Hřivna, L. (2004): The Effect of Sulphur Fertilisation on Yield and Technological Parameters of Wheat Grain. - Annales Universitatis Mariae CurieSkłodowska, Sec. E. 59(4): 1669-1678.

[47] Sahota, T. S. (2006): Importance of Sulphur in Crop Production. - Northwest Link, September, 10-12. 
[48] Shah, K. H., Memon, M. Y., Siddiqui, S. H., Imtiaz, M., Aslam, M. (2003): Response of Wheat to Foliarly Applied Urea at Different Growth Stages and Solution Concentrations. - Plant Pathology J. 2: 48-55.

[49] Shi, R., Zhang, Y., Chen, X., Sun, Q., Zhang, F., Romheld, V., Zou, C. (2010): Influence Of Long Term Nitrogen Fertilization On Micronutrient Density İn Grain Of Winter Wheat (Triticum Aestivum L.). - Journal of Cereal Science 51(1): 165-170.

[50] Singh, J., Singh, M., Jain, A., Bhardwaj, S., Singh, A., Singh, D. K., Bhusan, B., Dubey, S. K. (2013): An introduction ofplant nutrients and foliar fedilization: A Review. Amercian Journal of Experimental Agriculture 3: 258-32t.

[51] Soboka, S., Bultossa, G., Eticha, F. (2017): Physico Chemical properties in Relation to Bread Making Quality of Ethiopian Improved Bread Wheat (Triticum aestivum L) Cultivores Grown at Kulumsa, Arsi, Ethiopia. - Journal of Food Process Technology 8(11): 703.

[52] Tandon, H. L. S. (1986): Sulfur Research and Agricultural Production in India. 2nd ed. Fertilizer Development and Consultation Organisation, New Delhi, p.76.

[53] Tandon, H. L. S. (1991): Sulphur Research and Agricultural Production in India, 3rd Ed. - The Sulphur Institute: Washington, D.C. 140 pp.

[54] Uauy, C., Distelfeld, A., Fahima, T., Blechl, A., Dubcovsky, J. (2006): A Nac Gene Regulating Senescence Improves Grain Protein, Zinc, and Iron Content In Wheat. - Sci. 314: 1298-1301.

[55] Unal, S. S. (2002): Buğdayda Kalitenin Önemi ve Belirlenmesinde Kullanılan Ölçüler. Hububat 2002. Hububat Ürünleri ve Teknolojisi Kongre ve Sergisi, s:25-37.

[56] US Salinity Laboratory Staff. (1954): Diagnosis and İmprovement of, Saline and Alkaline Soils. - Richards, L. A. (ed.) USDA Agriculture Handbook B, No: 60, U. S. Gov. Printing Office, Washington, $160 \mathrm{P}$.

[57] Varga, B., Svečnjak, Z. (2006): The Effect of Late-season Urea Spraying on Grain Yield and Quality of Winter Wheat Cultivars under Low and High Basal Nitrogen Fertilization. - Field Crops Research 96: 125-132.

[58] Wang, S., Li, M., Liu, K., Tian, X., Li, S., Chen, Y., Jia, Z. (2017): Effects of Zn, macronutrients, and their interactions through foliar applications on winter wheat grain nutritional quality. - PloS one 12(7): e0181276. doi:10.1371/journal.pone.0181276.

[59] Waters, B. M., Uauy, C., Dubcovsky, J., Grusak, M. A. (2009): Wheat (Triticum Aestivum) Proteins Regulate The Translocation of Iron, Zinc, And Nitrogen Compounds From Vegetative Tissues To Grain. - Journal of Experimental Botany 60(15): 4263-4274.

[60] Xue, Y. F., Yue, S. C., Zhang, Y. Q., Cui, Z. L., Chen, X. P., Yang, F. C., Cakmak, I., McGrath, S. P., Zhang, F. S., Zou, C. Q. (2012): Grain and Shoot Zinc Accumulation in Winter Wheat Affected by Nitrogen Management. - Plant and Soil 361: 153-163.

[61] Yilmaz, A., Ekiz, H., Torun, B., Gultekin, I., Karanlik, S., Bagci, S. A., Cakmak, I. (1997): Effect of Different Zinc Application Methods on Grain Yield and Zinc Concentration in Wheat Grown on Zinc-deficient Calcareous Soils in Central Anatolia. Journal of Plant Nutrition 20(4): 461-471.

[62] Zadoks, J. C., Chang, T. T., Konzak, D. F. (1974): A Decimal Code for the Growth Stages of Cereals. - Weed Research 14: 415-421.

[63] Zareian, A., Abad, H. H. S., Hamidi, A., Mohammadi, G. N., Tabatabaei, S. A. (2013): Effect of Drought Stress and Potassium Foliar Application on Some Physiological Indices of Three Wheat (Triticum aestivum L.) Cultivars. - Annals of Biological Research 4(5): 71-74.

[64] Zhang, Y. Q., Sun, Y. X., Ye, Y. L., Karim, M. R., Xu, Y. F., Yan, P., Meng, Q. F., Cui, Z. L., Cakmak, I., Zhang, F. S., Zou, C. Q. (2012): Zinc Biofortification of Wheat Through Fertilizer Applications in Different Locations of China. - Field Crops Research 125: $1-7$.

[65] Zhao, F. J., Hawkesford, M. J., McGrath, S. P. (1999a): Sulphur Assimilation and Effects on Yield and Quality of Wheat. - Journal of Cereal Science 30(1): 1-17. 
[66] Zhao, F. J., Salmon, S. E., Withers, P. J. A., Evans, E. J., Monaghan, J. M., Shewry, P. R., McGrath, S. P. (1999b): Responses of Breadmaking Quality to Sulphur in Three Wheat Varieties. - Journal of Science Food and Agriculture 79: 1865-1874.

[67] Zhao, F. J., McGrath, S. P., Blake-Kalff, M. M., Link, A., Tucker, M. (2002): Crop Responses to Sulphur Fertilisation in Europe. - In: Proceedings of the International Fertiliser Society 504. Leek, UK: The International Fertiliser Society. 